\title{
Investigating the effect of financial literacy on the culture of investment in stock market among the citizens of Khoy
}

\author{
Kimia Ahmadzad Asl ${ }^{1}$, Atieh Bohrani ${ }^{2}$, Zahra Foroutani ${ }^{3}$
}

1.Ms. Student in Public Administration, Khoy, Iran., kymyaahmdzad@gmail.com

2.Assistant Professor, Department of Public Administration, Faculty of Management, Economics and Accounting, Payam-e-Noor University, Khoy, Iran

3.Assistant Professor, Department of Public Administration, Faculty of Management, Economics and Accounting, Payam-e-Noor University, Khoy, Iran

\begin{abstract}
Investing in stock exchange market is one of the ways for people to participate in economic development and bring small and wandering savings into productive activities. Despite the fact that many citizens in Iran are increasingly present in the financial markets, but they have always faced severe financial risks. Therefore, the present study seeks to analyze the effect of financial literacy on the culture of investment in the stock market among the citizens of Khoy. The statistical population of this study, which is a descriptive-survey research, consists of all citizens of Khoy, among them, 385 people were selected based on Cochran's formula as the statistical sample and due to the unknown size of the population. The standard questionnaire of Kandiabongomin et al. (2016) was used in this study to collect field data on financial literacy, and Nategh Golestan et al. (2013) questionnaire was used to assess the investment culture. Also, the method of studying structural equations and path analysis with the partial least squares (PLS) method by Smart-PLS software has been used in order to answer the questions and test the research hypotheses. According to the obtained results, personal attitude, personal skills, personal behavior and personal knowledge of Khoy citizens have a positive and significant effect on their culture of investment in the stock market.
\end{abstract}

Keywords: financial literacy, investment culture, stock market.

\section{Introduction and problem statement}

Financial literacy and economic preferences are important drivers of public health, income and well-being. As an important skill for successful economic life, financial literacy refers to the "a combination of awareness, knowledge, skills, attitudes and behaviors necessary to make sound economic decisions and ultimately achieve individual financial well-being" (Razen et al. , 5: 2020). The growth and development of the financial sector of the economy has led to the importance of financial literacy, and therefore, conducting research on the reasons for the development of financial sectors to understand the importance of the issue of financial literacy will be effective. Community culture is one of the topics that may be related to financial literacy. From an economic perspective, through a systematic change in time or risk preferences or a change in social norms about debt tolerance and the way that debt is repaid, and so on, culture may affect the financial knowledge and decision-making. Also, in psychological terms, culture may affect the financial knowledge and decision-making through differences in financial 
socialization or attitudes toward money. Among the related topics in this regard are the norms related to savings and debt, which can be an important factor in the relationship between culture and financial literacy (Davoli et al., 10: 2020). The importance of improving the financial literacy of investors has increased due to factors such as the development of new financial products, the complexity of financial markets, changes in economic, political and demographic factors. Because financial literacy and investment know-how; The jurisprudence of working with capital resources has increased access to, analysis, evaluation and production of information about wealth generation opportunities, and with the widespread use of new and intelligent technologies, these opportunities have also increased. However, studies show that individuals and households have major problems in understanding simple financial concepts such as the composite value of money, portfolio diversification, and the time value of money (Fart et al., 2016: 761). In other words, while the ability of such customers to evaluate and compare the risk characteristics of the returns of different financial products (in addition to their different costs) offered by various financial intermediaries, leads to improved competition in financial markets. Lack of understanding of economics and finance can be a deterrent to stock ownership. This is because a lack of financial literacy prevents people from participating in the stock market and the loss of welfare resulting from participating in the stock market. Also, due to the fact that uninformed investors are not able to take full advantage of the stock market and efficient investment, they lose the possibility of investing and making smart choices in the financial markets. Iran is no exception to this rule and the lack of financial literacy is clearly visible among different sections of society. In the last two years, due to the pervasiveness of the stock market in the country for reasons such as government support for the stock market, increasing investors' interest in participating in the stock market instead of depositing in banks and the plan to liberalize justice shares, the presence of citizens in The stock market is observed, while the study of the background of these people shows their limited and limited information and financial literacy in the field of stock market activity, which in itself can be the basis for emotional decisions, without support and full. It provided risk for this group of investors. Therefore, considering the importance of financial literacy and its role in the investment culture of citizens and turning to the existing research needs in this field, it seeks to answer the main question: what is the impact of citizens' financial literacy on their investment culture?

\section{Literature and theoretical foundations of research}

Understanding the concepts and skills associated with financial literacy has become essential because it enables the consumer to survive in modern society and to resist the diversity and complexity of existing financial products and services. It can be acknowledged that having financial skills has become more important in the last decade, so having financial literacy is an essential basis for preventing and solving financial problems, and in turn is vital for having a successful, healthy and happy life. Is (Mirzaei et al., 1398). In fact, the issue of financial literacy and the need to study it is important in the sense that the inadequacy of financial literacy overshadows the lives of individuals, family, friends and business partners due to inappropriate financial decisions, and this has adverse effects on society and It even reduces national wealth and ultimately reduces the level of financial well-being in society. In recent years, emerging and developed countries have been dealing with issues related to the level of financial literacy of their citizens (Nikolini, 2020). This is because investors are often faced with difficult economic and financial contexts, and the fact that financial illiteracy is one of the factors that has contributed to the spread of poverty, as well as the fact that financial decisions can have major negative consequences in financial situations Can not be hidden. Financial literacy is only part of the political response to empowering communities in financial markets (Cameron et al., 2014). Behavioral economics and investment psychology reflect the fact that people's behavior can improve the effectiveness of financial literacy programs; People will become more interested in planning their financial literacy when they realize that their specific investment behaviors will create prosperity. Individuals may act according to theories of economic rationality when faced with different decision-making options, and this may not lead to optimal financial decision- 
making without adequate financial literacy (Lee, 2020). In other words, investors with a good level of financial literacy perform better in their investment decisions than other investors, and this factor can have a positive effect on their investment performance because they have a higher level of financial literacy Financial literacy in recent years has created benefits for various groups, including governments, bankers, employers, various social groups, financial markets and other organizations, especially in developed countries. The importance of improving financial literacy has increased due to factors such as the development of new financial products, the complexity of financial instruments and markets, political change, and economic factors (Chen et al., 2016). Financial literacy can include concepts such as financial awareness, knowledge and science about financial products and financial institutions, or concepts such as financial skills such as the ability to calculate compound interest payments and, in general, financial ability to manage money and planning. Be financial; However, in practice, these concepts overlap and are common (Hassanzadeh, 1398: 96). Capital markets are very complex and are based on difficult and important decisions. Naturally, decision-makers must have good information versus financial literacy by examining individual knowledge or understanding and applying the basic concepts related to financial decisions and thus using products. Finance and services are measured (Clapper, 40: 2015). Therefore, investors, as decision makers in the field of economics, should have a reasonable level of financial information and the ability to analyze the financial market, which shows the importance of the position of financial literacy (Kramer et al., 2016); Because people who have a higher financial attitude and continue to have a good financial understanding, better manage their daily finances and long-term plans.

\section{1-2. Empirical background of the research}

Financial literacy has been studied from different aspects. The following is a brief description of some of the most relevant of these studies in Table (1):

Table 1: Internal and external background

\begin{tabular}{|c|c|c|}
\hline Achievement & Title & Researcher \\
\hline $\begin{array}{l}\text { They have found a strong link between their } \\
\text { financial literacy in the United States and their level } \\
\text { of financial literacy in their own country. In } \\
\text { particular, if a person from a country with moderate } \\
\text { financial literacy instead of a country with high } \\
\text { financial literacy, a standard deviation above } \\
\text { average, risk deviation, and interest rates in the } \\
\text { United States increases by } 4 \% \text {, a } 9 \% \text { increase over } \\
\text { average literacy Finance in the study sample will } \\
\text { increase by } 43 \% \text {. The cultural components behind } \\
\text { this observed relationship include a strong emphasis } \\
\text { on patience, long-term orientation, and risk } \\
\text { avoidance in the country of origin. }\end{array}$ & $\begin{array}{c}\text { Adult culture and } \\
\text { financial literacy: } \\
\text { Evidence from the } \\
\text { United States }\end{array}$ & $\begin{array}{c}\text { Davoli et al. } \\
\quad(2020)\end{array}$ \\
\hline $\begin{array}{l}\text { Lower levels of financial literacy lead to irrational } \\
\text { financial decisions about investments, pension } \\
\text { funds, as well as savings and debt. While measuring } \\
\text { financial literacy is difficult given its qualitative } \\
\text { nature, creating the right measure for financial } \\
\text { literacy is critical for both marketers and } \\
\text { policymakers. }\end{array}$ & $\begin{array}{l}\text { When financial } \\
\text { literacy is } \\
\text { confronted with } \\
\text { textual analysis: a } \\
\text { conceptual review }\end{array}$ & Lee (2019) \\
\hline
\end{tabular}


Financial literacy is positively related to male gender and father education. Financial literacy is positively associated with patience. Adolescents' behavior is also positively associated with various measures of risk-taking, but negatively with financial literacy and economic priorities, they are important drivers of public health, income, and well-being. They examine the gap between studies in financial literacy and research on economic priorities by examining how they interact with each other and adolescents' field behavior.

Our empirical evidence shows that people with higher financial literacy experience less financial disputes. When buying financial products and services leads to financial disparities, people with higher financial literacy are severely handling the problem. In addition, personal characteristics, such as gender, employment status, and household income, are key factors influencing the chances of a financial dispute.

According to the research results, the main category including education should include general topics of income and savings management, risk management and expenditure management, which can be used to design, develop and implement a financial literacy training program in Iran.

Individual mindsets, accounting information, economic information and personal financial needs influence investment decisions in Iran. While there is no significant relationship between financial literacy level and investors' decisions. It was also found that age, gender, marital status do not have a significant relationship with investors 'decisions, but the level of education has a direct and significant relationship with investors' financial literacy. In addition, the results show that considering the level of understanding of investors' risk, their level of risktaking influences their investment decisions. Financial literacy, financial knowledge and perceived risk have a significant effect on investment decisions and perceived risk negatively modulates the relationship between financial knowledge and investment decision, while in the relationship between literacy It does not moderate finances and investment decisions.

Financial literacy and money management and their components have a positive and significant effect on the personal financial management of Tehran Stock Exchange investors.
Financial literacy, economic

preferences and

Rosen et al.

adolescent behavior

(2018)

\section{Presenting a model Kazempour \\ of financial literacy Dizaji et al. \\ training in Iran \\ (1399) \\ using data \\ foundation \\ theorizing method \\ The effect of \\ financial literacy \\ Hassanzadeh \\ et al. (1398)}

and risk perception

on investment

selection in Tehran

Stock Exchange

\begin{tabular}{|c|c|}
$\begin{array}{c}\text { Investigating the } \\
\text { role of financial } \\
\text { literacy and } \\
\text { financial } \\
\text { knowledge in } \\
\text { investors' decision } \\
\text { to invest }\end{array}$ & $\begin{array}{c}\text { Mir } \\
\text { Sohammadrabadi } \\
\text { and } \\
\text { Shakarian } \\
(1398)\end{array}$ \\
$\begin{array}{c}\text { Investigating the } \\
\text { role of financial } \\
\text { literacy and money } \\
\text { management on } \\
\text { investors' personal } \\
\text { financial } \\
\text { management }\end{array}$ \\
\hline
\end{tabular}




\section{2-2. Conceptual model of research}

All research studies are based on a conceptual framework, which identifies the variables and the relationships between them (Driva et al., 2016). This conceptual framework is the model by which the researcher theorizes about the relationships between the factors identified in creating the important problem. This theory can not necessarily be the word of the researcher and can be logically derived from the results of previous research on the issue (Khaki, 1999). Because any field and survey research requires a mind map and conceptual model that is drawn in the form of appropriate analytical tools, variables and relationships between them. Candiabongomin et al. (2016) explained financial literacy in the form of a conceptual model. According to their proposed model, the four components of attitude, skill, behavior and knowledge are the dimensions of financial literacy. Therefore, in the present study, the researcher seeks to measure the dimensions of this model on the culture of investing citizens in the stock market. Therefore, the conceptual model of this research is as follows:

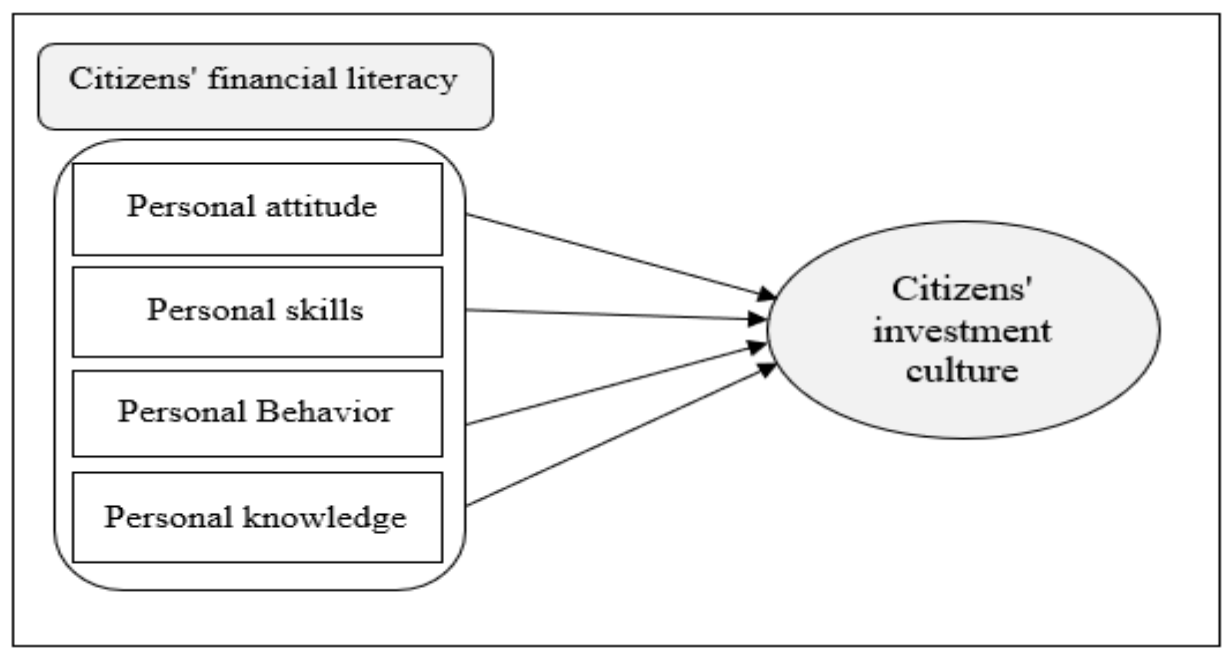

Figure 1. Conceptual model of research

\section{Research methodology}

The present study is one of the types of applied studies and the strategy used in it is one of the types of survey and correlation and one of the types of quantitative and one-section studies. The statistical population of the present study is all citizens of Khoy who are looking to invest in the stock market. Due to the unknown size of the population, the Cochran's formula was used to determine the sample for unknown communities. Based on this, a sample size of 385 people was determined and simple random sampling was performed among those citizens who were in contact with stock exchange brokerage companies. Data collection in this research is field and also for compiling the theoretical foundations of the research from the library method and reviewing the documents and available resources and a standard questionnaire with a 5-point Likert scale (strongly agree to strongly disagree), was done. Thus, in the present study, in order to collect field data related to financial literacy, the standard questionnaire of Candiabongomin et al. (2016) and in order to collect data on factors affecting investment culture from the standard questionnaire of Nategh Golestan et al. 1392) has been used. It is worth mentioning that in the present study, standard questionnaires were used to measure the variables in order to maintain the validity of the research. In addition, in order to make the questionnaires more reliable, it has been approved by the supervisors and consultants, and Cronbach's alpha coefficient has been used to assess the reliability of the questionnaire. 
Table 2. Results of calculating the reliability of the questionnaire

\begin{tabular}{|c|c|c|c|}
\hline $\begin{array}{c}\text { Number } \\
\text { of } \\
\text { questions }\end{array}$ & $\begin{array}{c}\text { Cronbach's } \\
\text { alpha value }\end{array}$ & Component & \\
\hline 8 & $0 / 824$ & Citizens' attitudes & \multirow{2}{*}{$\begin{array}{c}\text { Independent } \\
\text { variables }\end{array}$} \\
\hline 7 & $0 / 812$ & Citizens' skills & \multirow{2}{*}{$\begin{array}{c}\text { The dependent } \\
\text { variable }\end{array}$} \\
\hline 6 & $0 / 887$ & Citizen behavior & Citizens' knowledge \\
\hline 6 & $0 / 871$ & $\begin{array}{c}\text { Citizens' investment } \\
\text { culture }\end{array}$ & \multicolumn{2}{|c|}{ The whole questionnaire } \\
\hline 10 & $0 / 734$ & $0 / 984$ & \multicolumn{2}{|c}{} \\
\hline 30 & \multicolumn{2}{|c|}{}
\end{tabular}

It is worth mentioning that in order to answer the questions and test the research hypotheses, the method of studying structural equations and path analysis using the partial least squares (PLS) method has been used. Also, in the descriptive statistics section, common statistical software such as Excel and SPSS were used, and in the inferential statistics section, Smart-PLS software was used.

\section{Research findings}

\section{4-1. Descriptive findings}

The descriptive findings of the present study are summarized in Table (3):

Table 3. Results of descriptive findings

\begin{tabular}{|c|c|c|c|}
\hline Frequency & Abundance & \multicolumn{2}{|c|}{ Variable } \\
\hline 59 & 225 & Man & \multirow[t]{2}{*}{ Gender } \\
\hline 41 & 160 & Female & \\
\hline 27 & 102 & $\begin{array}{c}\text { Less than } 25 \\
\text { years }\end{array}$ & \multirow[t]{5}{*}{ Age } \\
\hline 35 & 137 & $\begin{array}{c}\text { Between } 25 \text { and } \\
35 \text { years }\end{array}$ & \\
\hline 21 & 81 & $\begin{array}{c}\text { Between } 35 \text { and } \\
45 \text { years }\end{array}$ & \\
\hline 12 & 48 & $\begin{array}{c}\text { Between } 45 \text { and } \\
55 \text { years }\end{array}$ & \\
\hline 5 & 17 & $\begin{array}{c}\text { Older than } 55 \\
\text { years }\end{array}$ & \\
\hline 7 & 26 & $\begin{array}{c}\text { Above diploma } \\
\text { and below }\end{array}$ & \multirow{4}{*}{ education } \\
\hline 47 & 183 & Bachelor & \\
\hline 37 & 141 & MA & \\
\hline 9 & 35 & phd & \\
\hline
\end{tabular}




\section{4-2. Inferential findings}

In this study, after collecting information, to classify the information, generalize the results and finally the test Hypotheses have been performed using inferential statistical techniques.

\section{4-2-1. Validity and reliability of research}

For convergent validity, the mean of extracted variance (AVE) and composite reliability (CR) should be calculated. Whenever one or more attributes are measured, the correlation between these measurements provides two important validity indicators. If the correlation between factor loads is high, the questionnaire has convergent validity. This correlation is necessary to ensure that the test measures what needs to be measured

Table 4. Results of mean variance extracted from research structures

\begin{tabular}{|c|c|c|c|}
\hline Variables & AVE & $\begin{array}{c}\text { Composite } \\
\text { reliability }\end{array}$ & $\begin{array}{c}\sqrt{\text { AVE }} \\
\text { Convergent } \\
\text { validity }\end{array}$ \\
\hline Citizens' attitudes & $0 / 884$ & $0 / 968$ & $0 / 781$ \\
\hline Citizens' skills & $0 / 671$ & $0 / 890$ & $0 / 819$ \\
\hline Citizen behavior & $0 / 824$ & $0 / 934$ & $0 / 908$ \\
\hline Citizens' knowledge & $0 / 902$ & $0 / 951$ & $0 / 925$ \\
\hline Citizens' investment culture & $0 / 789$ & $0 / 944$ & $0 / 921$ \\
\hline
\end{tabular}

Divergent validity in PLS software is measured in two ways: Transverse load test method (cross-factor loads) Fornlow-Larker method in which the relationship between a structure and its characteristics is compared with the relationship between that structure and other structures. This test also measures the validity of the diagnosis at the level of hidden variables. According to this criterion, a latent variable should have more scatter among its receptors than other latent variables. The second criterion is that the AVE root of a structure must be greater than the correlation of that structure with other structures. This indicates that the correlation of that structure with its markers is more than its correlation with other structures. According to research by Hensler et al. (2015), about $72.08 \%$ of the articles analyzed by Smart-PLS software used this test to confirm diagnostic validity. This index will be obtained by combining the tables of correlation values between the latent variables and the mean of the extracted variance.

Table 5. Comparison of the AVE root of a variable with the correlation of that variable with other research variables

\begin{tabular}{|c|c|c|c|c|c|}
\hline & $\begin{array}{c}\text { Citizens' } \\
\text { attitudes }\end{array}$ & $\begin{array}{c}\text { Citizens' } \\
\text { skills }\end{array}$ & $\begin{array}{c}\text { Citizen } \\
\text { behavior }\end{array}$ & $\begin{array}{c}\text { Citizens' } \\
\text { knowledge }\end{array}$ & $\begin{array}{c}\text { Citizens' } \\
\text { investment } \\
\text { culture }\end{array}$ \\
\hline Citizens' attitudes & $0 / 940$ & & & & \\
\hline Citizens' skills & $0 / 124$ & $0 / 819$ & & & \\
\hline Citizen behavior & $0 / 312$ & $0 / 504$ & $0 / 908$ & & \\
\hline Citizens' knowledge & $0 / 418$ & $0 / 472$ & $0 / 304$ & $0 / 952$ & \\
\hline $\begin{array}{c}\text { Citizens' investment } \\
\text { culture }\end{array}$ & $0 / 329$ & $0 / 369$ & $0 / 622$ & $0 / 401$ & $0 / 921$ \\
\hline
\end{tabular}




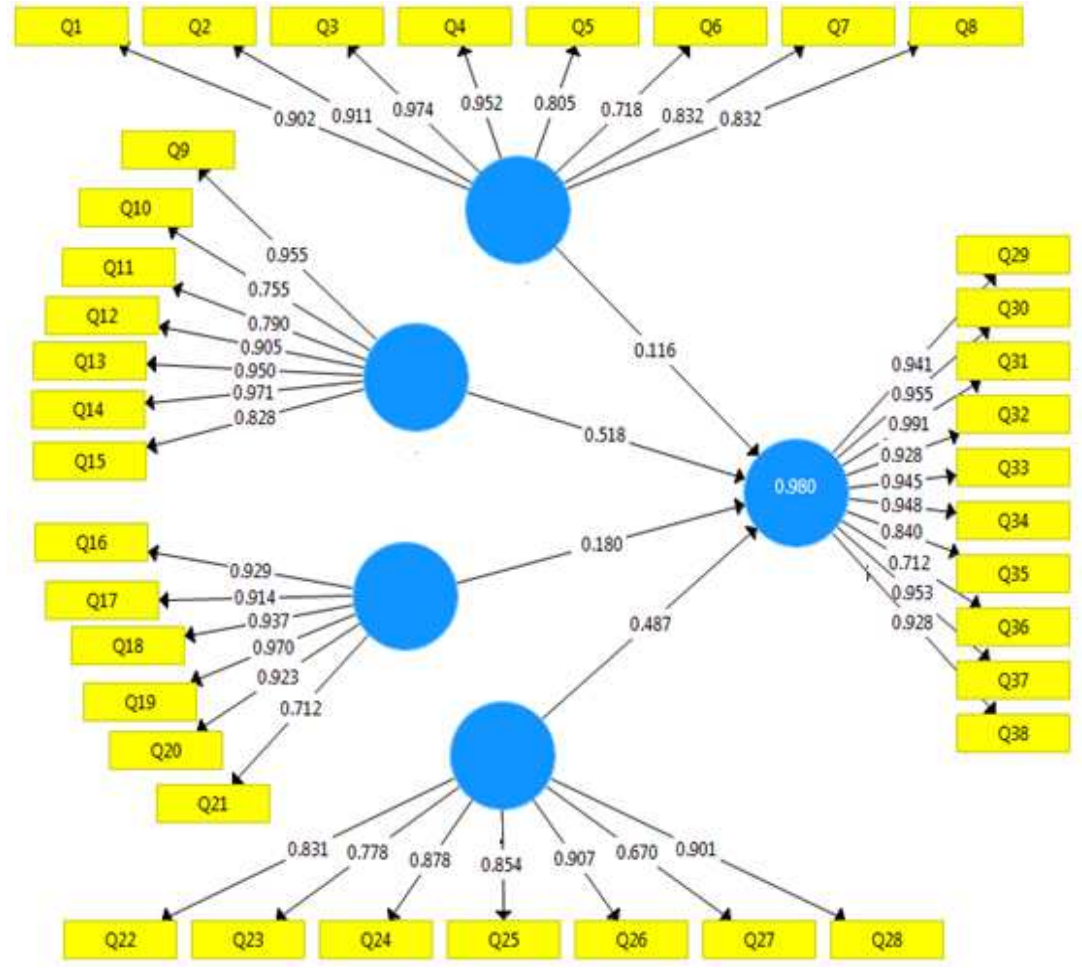

Figure 3. Research model in the case of estimating standard coefficients

\section{4-2-2. Methods of evaluating shaping models}

The coefficient of determination (R2) is a measure that indicates the amount of change in each of the dependent variables of the model, which is explained by independent variables. The value of $\mathrm{R} \wedge 2$ is given only for the endogenous variables of the model and its value is zero for exogenous structures. The higher the value of R2 related to the endogenous structures of the model, the better the fit of the model (Hanafizadeh and Zare Ravasan, 2012). According to the coefficient of determination of the model in the model, it can be said that citizens' attitudes, citizens' skills, citizens' behavior and citizens' knowledge together have been able to explain 0.980 of the variable variance of citizens' investment culture; Researchers have introduced three values of $0.19,0.33$ and 0.67 as the criterion values for weak, medium and strong values of R2. Based on this, it can be concluded that the model has a high predictability. The remaining amount is related to the forecast error and can include other factors affecting the investment culture of citizens.

\section{Quality test of measurement model or subscription index}

This index is calculated by the subscription index with cross validity. This index actually measures the path model's ability to predict observable variables through the values of their corresponding hidden variables. Since all values are positive, the model is of good quality.

Table 6. Quality test of the measurement model or subscription index

\begin{tabular}{|c|c|}
\hline$(\mathbf{1}-\mathbf{s s e} / \mathbf{s s o})=\mathbf{Q}^{\mathbf{2}}$ & Variables \\
\hline $0 / 781$ & Citizens' attitudes \\
\hline $0 / 451$ & Citizens' skills \\
\hline $0 / 617$ & Citizen behavior \\
\hline $0 / 581$ & Citizens' knowledge \\
\hline $0 / 659$ & Citizens' investment culture \\
\hline
\end{tabular}


As the table above shows, all Q2 values are substantially higher than zero, thus supporting the model's predictive fit for endogenous latent variables. The final evaluation examines the effect sizes of $\mathrm{f} 2$ and $\mathrm{q} 2$. For each effect in the path model, the effect size can be estimated using $\mathrm{f}$ square. The magnitude of the effect of $\mathrm{f} 2$ is proportional to the variation of $\mathrm{R} 2$ on the part of the variance of the endogenous latent variable that remains unexplained in the model. According to Cohen, the values $0.02,0.15$ and 0.35 for $\mathrm{f} 2$ represent small, medium and large effects, respectively. To calculate this coefficient, we first run the model completely and write down the values of R2. In the next step, we delete an independent path variable and run the model in the software again. Then we put it in the following formula (Azar and Gholamzadeh, 2016; 238). In this section, the consequences variable has been removed.

$$
\begin{gathered}
\mathrm{f}^{2}=\left(\mathrm{R}^{2} \text { included }-\mathrm{R}^{2} \text { excluded }\right) /\left(1-\mathrm{R}^{2} \text { included }\right) \\
\mathrm{f}^{2}=0.980-0.955 / 1-0.980=0.26
\end{gathered}
$$

Due to the value of 0.25 , the research model has a strong desirability. There is a similar procedure for calculating the size of the $\mathrm{q} 2$ effect. However, instead of R2 values, Q2 values of predictive fit are used as input (after performing the waiver procedure). The following formula is used to calculate the q2 index (Azar and Gholamzadeh, 2016; 238).

$$
\begin{gathered}
\mathrm{q}^{2}=\left(\mathrm{Q}^{2} \text { included }-\mathrm{Q}^{2} \text { excluded }\right) /\left(1-\mathrm{Q}^{2} \text { included }\right) \\
\mathrm{q}^{2}=0.659-0.541 / 1-0.659=0.35
\end{gathered}
$$

According to the value of 0.35 , the research model has a strong desirability.

General results of research hypotheses

Table (7) can also show the results of all research hypotheses:

Table 7. Test hypotheses test results

\begin{tabular}{|c|c|c|c|c|}
\hline $\begin{array}{c}\text { Reject or } \\
\text { not reject } \\
\text { the } \\
\text { hypothesis }\end{array}$ & meaning & $\begin{array}{c}\text { Amara } \\
\mathrm{t}\end{array}$ & $\begin{array}{c}\text { Standardized } \\
\text { path } \\
\text { coefficient } \beta\end{array}$ & \multicolumn{1}{c|}{ theories } \\
\hline $\begin{array}{c}\text { No } \\
\text { rejection }\end{array}$ & $\operatorname{Sig}<0.05$ & $9 / 936$ & $0 / 116$ & $\begin{array}{l}\text { Personal attitude of Khoy citizens } \rightarrow \text { The } \\
\text { culture of their investment in the stock market }\end{array}$ \\
\hline $\begin{array}{c}\text { No } \\
\text { rejection }\end{array}$ & $\operatorname{Sig}<0.05$ & $9 / 390$ & $0 / 548$ & $\begin{array}{l}\text { Personal skills of Khoy citizens } \\
\text { culture of investing in the stock market }\end{array}$ \\
\hline $\begin{array}{c}\text { No } \\
\text { rejection }\end{array}$ & $\operatorname{Sig}<0.05$ & $2 / 520$ & $0 / 180$ & $\begin{array}{l}\text { Personal behavior of Khoy citizens } \rightarrow \text { The } \\
\text { culture of their investment in the stock market }\end{array}$ \\
\hline $\begin{array}{c}\text { No } \\
\text { rejection }\end{array}$ & $\operatorname{Sig}<0.05$ & $7 / 322$ & $0 / 487$ & $\begin{array}{l}\text { Personal knowledge of Khoy citizens } \rightarrow \text { The } \\
\text { culture of their investment in the stock market }\end{array}$ \\
\hline
\end{tabular}

\section{Discussion and conclusion}

In recent years, financial literacy has created benefits for various groups, including governments, bankers, employers, various social groups, financial markets and other organizations, especially in developed countries. The importance of improving financial literacy has increased due to factors such as the development of new financial products, the complexity of financial instruments and markets, political change and economic factors (Al-Tamimi and Benkley, 2009: 98). Given the abundance of investment options and the expansion of marketing, this process is effective only when it is possible to choose from information and financial literacy. University education in finance and accounting and information provided by the public and private sectors, the Internet and financial education courses are among the sources of financial literacy. The aim 
of this study was to measure the impact of financial literacy on the culture of investing in the stock market among the citizens of Khoy and the following results were obtained: Hypothesis 1: The financial attitude of the citizens of Khoy affects the culture of their investment in the stock market. According to the results obtained from the path coefficient and t-statistic, in the table and diagrams of Chapter Four, the personal attitude of the citizens of Khoy has a significant effect on their investment culture in the stock market. Considering the path coefficient, it can be said that the effect of personal attitude of the citizens of Khoy city on their investment culture in the stock market is positive and significant, because the path coefficient obtained is positive. Therefore, by improving the personal attitude of the citizens of Khoy, their investment culture in the stock market increases and with its decline, their investment culture in the stock market decreases. Therefore, this hypothesis is accepted. Findings based on the studies of Hassanzadeh et al. (1398), Hypothesis 2: The financial skills of the citizens of Khoy affect the culture of investing in the stock market. According to the results obtained from the path coefficient and tstatistics, in the table and diagrams of Chapter Four, the personal skills of the citizens of Khoy have a significant effect on their investment culture in the stock market. Considering the path coefficient, it can be said that the effect of personal skills of Khoy citizens on their investment culture in the stock market is positive and significant, because the path coefficient obtained is positive. Therefore, by improving the personal skills of the citizens of Khoy, their investment culture in the stock market increases and with its decline, their investment culture in the stock market decreases. Therefore, this hypothesis is accepted. Hypothesis 3: The financial behavior of the citizens of Khoy affects the culture of their investment in the stock market. According to the results obtained from the path coefficient and t-statistics, in the table and diagrams of Chapter Four, the personal behavior of the citizens of Khoy has a significant effect on their investment culture in the stock market. Considering the path coefficient, it can be said that the effect of personal behavior of Khoy citizens on their investment culture in the stock market is positive and significant, because the path coefficient obtained is positive. Therefore, by improving the personal behavior of the citizens of Khoy, their investment culture in the stock market increases and with its decline, their investment culture in the stock market decreases. Therefore, this hypothesis is accepted. Hypothesis 4: The financial knowledge of the citizens of Khoy affects the culture of their investment in the stock market. According to the results obtained from the path coefficient and t-statistic, in the table and diagrams of Chapter Four, the personal knowledge of the citizens of Khoy has a significant effect on their investment culture in the stock market. Considering the path coefficient, it can be said that the effect of personal knowledge of Khoy citizens on their investment culture in the stock market is positive and significant, because the path coefficient obtained is positive. Therefore, with the knowledge of the personal attitude of the citizens of Khoy, their investment culture in the stock market increases and with its decrease, their investment culture in the stock market decreases. Therefore, this hypothesis is accepted. This finding is consistent with the research of Mir Mohammadi Sadradab et al. (1398)

\section{5-4- Practical suggestions}

Teach citizens the scientific methods of earning more money in the field of economic activity so that they can use it to earn more money.

$>$ Learning that citizens can well predict what kind of investment will be more profitable in the future and what to invest in.

$>$ Improve citizens' financial literacy so that they can advise others on how to make more money.

$>$ Remind citizens about learning how to save.

$>$ Increasing the appropriate scientific information of citizens about how to measure, especially in the field of economic activity

$>$ Teaching scientific methods of saving properly and scientific planning for saving to citizens.

$>$ Study the risks in the market to invest in risks that are likely to be profitable. 


\section{References}

Cameron, M. P., Calderwood, R., Cox, A., Lim, S., \& Yamaoka, M. (2014). Factors associated with financial literacy among high school students in New Zealand. International Review of Economics Education, 16, Part A, 12-21. doi: http://dx.doi.org/10.1016/j.iree.2014.p07.006

Chen, Ch.H., Linb, Sh.J., Tang, D.P., Hsiao, Y. J. (2016). The relationship between financial disputes and financial literacy. Pacific-Basin Finance Journal. 36. p46-65.

Davolia, M., Rodríguez-Planas, N. (2020). Culture and adult financial literacy: Evidence from the United States. Economics of Education Review. Volume 78, p 102013

Driva, A., Lührmann, M., \& Winter, J. (2016). Gender differences and stereotypes in financial literacy: Off to an early start. Economics Letters, 146, p143-146. doi: http://dx.doi.org/10.1016/j.econlet.2016.07.029

Fort, M., Manaresi, F., \& Trucchi, S. (2016). Adult financial literacy and households financial assets: The role of bank information policies. Economic Policy, No31(88),p 743-782

Klapper, L., Lusardi, A., \& Van Oudheusden, P. (2015). Financial literacy around the world. World Bank. Washington DC: World Bank.

Kramer, M. M. Financial Literacy, Confidence and Financial Advice Seeking. Journal of Economic Behavior \& Organization. doi: http://dx.doi.org/10.1016/j.jebo.2016.08.016.

$\mathrm{Li}, \mathrm{X}$. (2020). When financial literacy meets textual analysis: A conceptual review. Journal of Behavioral and Experimental Finance (2020), doi: https://doi.org/10.1016/j.jbef.2020.100402

Nicolini, G. (2019). Financial Literacy in Europe: Assessment Methodologies and Evidence from European Countries. Abington: Routledge

Mirzaei, Maryam and Shirazian, Zahra (1398). Investigating the role of financial inclusion and financial literacy on the perceived value of investment from the perspective of investors of Nehran Stock Exchange. Tehran Securities Financial Knowledge Quarterly, No. 41, pp. 143125 . 